\title{
Post-mining policies and practices in the Eastern USA coal region
}

\author{
Jeff Skousen · Carl E. Zipper
}

Received: 2 July 2014/Revised: 5 August 2014/Accepted: 5 August 2014/Published online: 3 October 2014

(C) The Author(s) 2014. This article is published with open access at Springerlink.com

\begin{abstract}
Surface coal mines prior to 1950 in the USA were generally left without any reclamation. As government regulations advanced since then, mine operators were required to backfill the area and plant grasses or trees. After the federal Surface Mining Control and Reclamation Act (SMCRA) was passed in 1977 in the USA, mine operators were required to conduct pre-mining analyses of the site and to designate a land use that could be achieved after mining. Successful reclamation, as needed to satisfy today's societal demands, requires engineering, design, and purposeful reconstruction of the full mining disturbance, not just its surface, and control of waters leaving the mine site. Effective reclamation on modern American coal mines is fully integrated with the mining operation. A suitable and effective postmining land use that is sustainable for future generations is crucial to the long-term success and profitability of the mining business and to the future economic benefits of the landowner. Accepted post-mining land uses in the USA are: (1) prime farmland, (2) hay land and pasture, (3) biofuel crops, (4) forestry, (5) wildlife habitat, and (6) building site development. Policies and regulations for each post-mining land use were developed and practices to achieve successful and sustainable land uses were established. Post-mining conditions should provide ecosystem services and produce lands capable of supporting societal needs in the future.
\end{abstract}

Keywords Biofuel · Commercial development · Laws and regulations · Pasture - Prime farmland · Reforestation · Water quality $\cdot$ Wildlife habitat

\section{Introduction}

Mining produces materials that are essential to human needs. Reclamation of land affected by mining to a useful and productive state is also essential to meeting those needs. Effective reclamation of land is important to the long-term success and profitability of the mining business and to the future economic well-being of the landowner (ACSMP 2011). The federal law governing coal surface mining in the USA requires reclamation to achieve a post-

J. Skousen $(\bowtie)$

West Virginia University, Morgantown, WV 26506, USA

e-mail: jeff.skousen@mail.wvu.edu

\section{E. Zipper}

Virginia Polytechnic Institute and State University, Blacksburg, VA 24061, USA mining land use potential that is equal to or better than the pre-mining capability. Laws governing mining in other nations have similar requirements.

The history of reclamation in the USA can be viewed as a progression from rehabilitation toward restoration. Today, some mined lands are reclaimed to developed land uses, such as industrial, commercial, and residential sites, but most are not. For lands not reclaimed to such uses, rehabilitation was formerly allowed. If such lands were stable, vegetated, and did not produce excessive erosion or poor water quality, the "reclamation" process that produced such lands was approved by regulators. Although full restoration is not required today, the public and regulatory agencies expect that some elements of "restoration" will be achieved. The public expects that "reclamation" of mined lands will include providing soils, hydrology, and landscapes to allow the return of ecosystem services that 
existed prior to disturbance. Such ecosystem services may include developing habitats for diverse wildlife, microorganism, and fish species; enhancing hydrologic processes that accept and store water, and promoting water infiltration and purification; and supporting productive growth of plants, such as trees or grasses for harvesting. An ecosystem with the foundations of productive and fertile soils, clean water, and stable landscapes will proceed through natural plant succession to an ecologically sustainable condition, and will create an aesthetically pleasing and healthy environment for humans.

There are four categories of land that are being surface mined for coal, and the distinct climate and geology/soils of these areas largely dictate the post-mining land use. These four types are: (1) forest in the Eastern USA, (2) prime farmland in the Midwestern USA, (3) savannah and pasture in the Western USA, and (4) range land in the Western USA.

The Eastern USA surface mined areas are predominantly forested landscapes (Figs. 1, 2). The climate and soils/geology of the central Appalachian Mountains are conducive to some of the best hardwood forest growth in the world (Hicks 1998). The climate is continental with cold snowy winters especially at high elevations to warm, humid summers. Average precipitation varies from $200 \mathrm{~cm}$ at high elevations to $100 \mathrm{~cm}$ toward the western part of the region. The geology is sedimentary; most of the rocks are sandstone, siltstone, and shale, with inter-bedded coal seams. The strata are generally flat-lying, with most sedimentary beds oriented within a few degrees of horizontal.

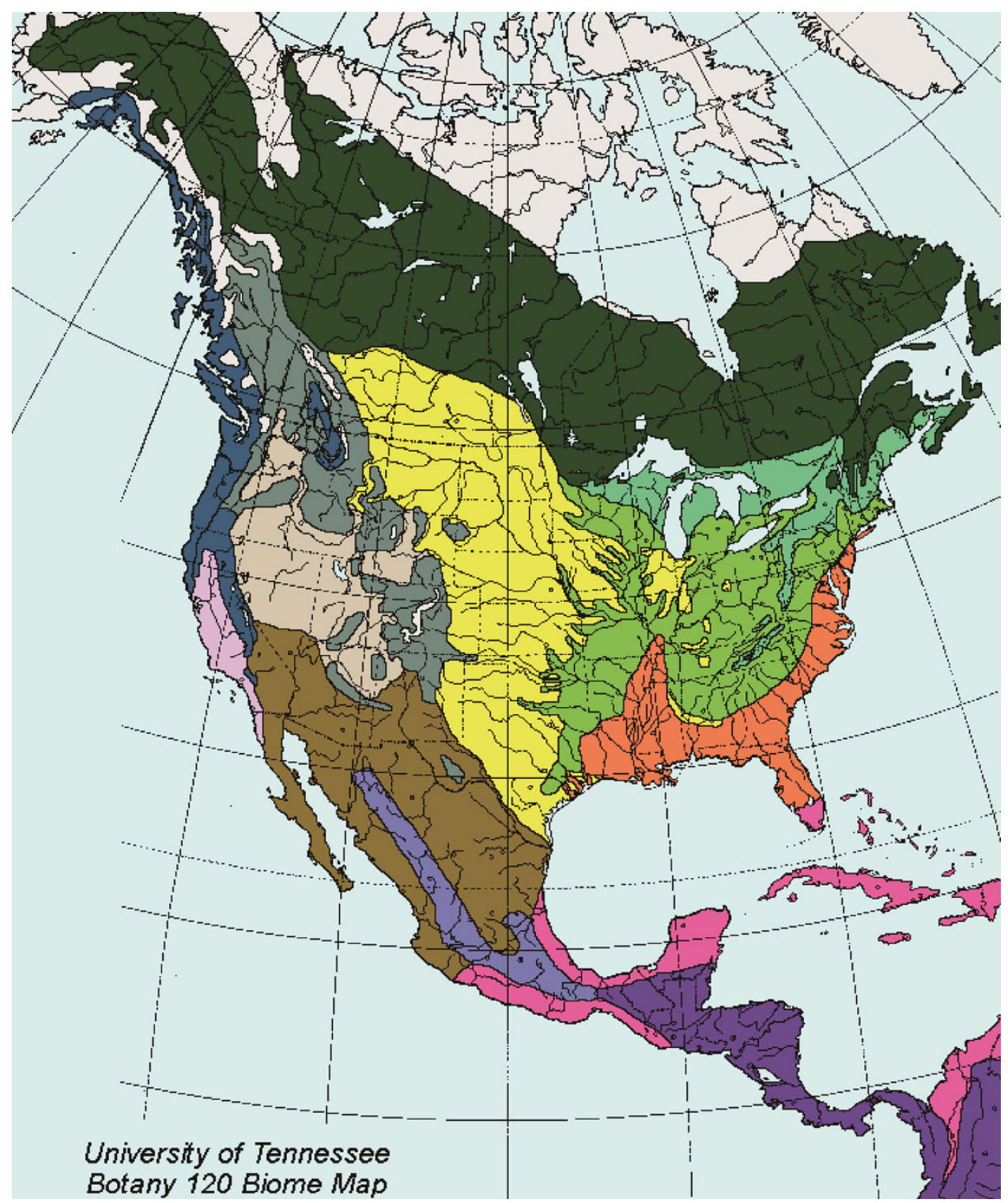

Fig. 1 Forests in North America. The Mixed Deciduous Forest is shown in light green (Figure courtesy of the University of Tennessee, Department of Forestry, Knoxville, TN) 


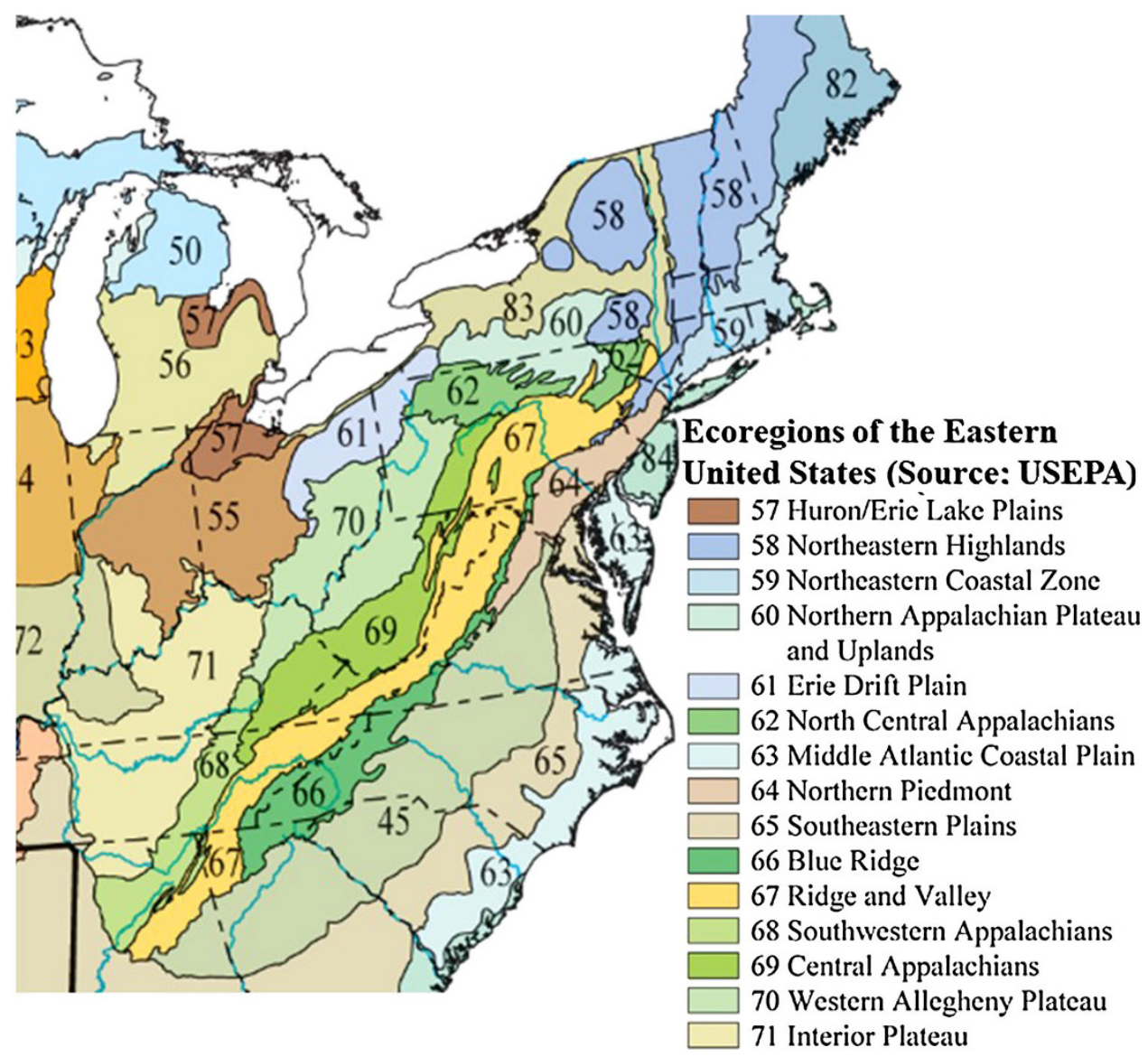

Fig. 2 The Mixed Deciduous Forest in Appalachian extends from New York in the north to Alabama in the south

The region's highlands occur as remnants of an ancient plateau which has been heavily dissected, causing steep side slopes to become the predominant landforms. Soils on those side slopes are generally thin $(<1 \mathrm{~m})$, but soils can occur with greater depth on the remaining ridge tops and along waterways. Native forest soils in the region are typically mildly acidic and often contain high concentrations of $\mathrm{Fe}$ and $\mathrm{Al}$, and low concentrations of $\mathrm{P}, \mathrm{K}, \mathrm{Ca}$, and Mg (Slagle et al. 2004; Farr et al. 2009).

Appalachian forests are a globally significant ecological resource (Riitters et al. 2000). These forests host an assemblage of nearly 40 commercially important tree species and a rich understory of grasses and herbs that vary across this mountainous landscape forming what is among the most diverse non-tropical ecosystems in the world (Ricketts et al. 1999). These forests provide ecosystem services including carbon storage, watershed and water quality protection, and habitat for plants and fauna. Appalachian forests supply timber to local users as well as the world economy, and the forest industry is a major employer. Coal surface mining, however, has caused forest fragmentation and a net loss of productive forestland (Drummond and Loveland 2010).
The Midwestern USA coal mining region is generally located in some of the highest producing agricultural areas of the world. The writers of the SMCRA recognized that coal could be found underneath some of the most productive agricultural soils in the United States. These are lands that have the soil quality, growing season and moisture supply needed for producing high yields of crops sustainably. Soil and site factors include suitable $\mathrm{pH}$ and acidity and alkalinity levels, low levels of salt, good permeability to water and air, favorable temperatures and growing season length, few or no rocks, not flooded frequently or have a high water table, and not erodible (Dunker and Barnhisel 2000; Dunker et al. 2012). Reclamation success on prime farmlands is determined by the restored soil's capability to produce equal or greater yields of crops previously grown on the site or on adjacent areas under the same levels of management.

The areas mined for coal in the Western USA are composed of a variety of soil/geology and climatic types. The two most common ecosystems disturbed are the open grassland areas (such as those where lignite and coal are mined in Texas, Montana and North Dakota) and range land in Montana, Wyoming, and New Mexico. These areas are reclaimed to vegetation communities similar to those that 


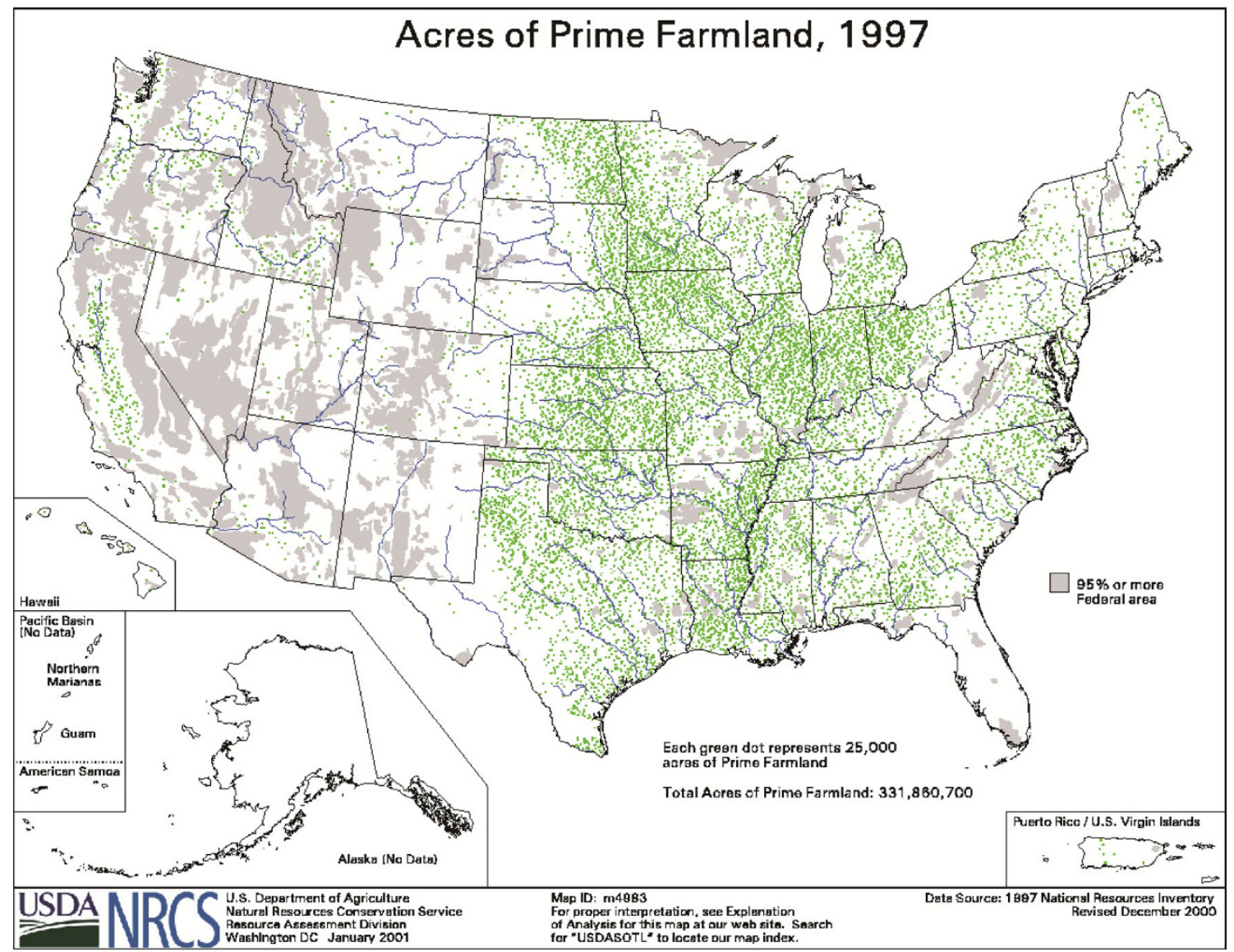

Fig. 3 Prime farmland areas of the USA. The major areas of coal mining with prime farmland are in Illinois and western Kentucky

existed before mining and are composed of native species. These lands are recolonized by plant and animal species from nearby undisturbed areas and mining companies attempt to re-establish the ecosystem services which originally existed before mining (Fig. 3).

This paper will deal primarily with the coal mining areas in the Eastern and Midwestern USA, which involve reclamation to the post-mining land uses of hay land, pasture, forestry, wildlife habitat, and prime farmland.

\section{Reclamation practices from 1940-1977}

Surface coal mining disturbed approximately 2.5 million ha (6 million acres) from 1930 to 1977 in the USA (Paone et al. 1978; Plass 2000). Most of the early surface mining in the USA was conducted in the Eastern USA where abundant coal reserves were known and had been mined by underground methods for decades. After World War II with the development of larger earth-moving equipment, surface mining advanced as a more prominent mining method. Large areas of disturbed land were left with little to no reclamation because there were no legal requirements to reclaim the land (Fig. 4).
Early surface-mine reclamation laws required some soil, subsoil, or overburden be placed back in the excavated area, but little emphasis was given to revegetation. Conifers and some hardwood trees were planted on some of the regraded areas (Limstrom 1960; Brown 1962; Plass 2000; Ashby 2006). At the time, reclamation was intended only to reshape the land and to establish readily available trees or shrubs from nearby sources. The trees planted on these early reclamation attempts were mostly pines (Pinus spp.) and black locust (Robinia pseudoacacia L.) - if anything was planted at all. Species such as the non-native exotic autumn olive (Elaeagnus umbellata Thumb.) and the native Virginia pine (Pinus virginiana Mill.), red pine (P. resinosa Ait.), and eastern white pine (Pinus strobus L.) were transplanted as seedlings and grew well in many early reforestation studies (Minkler 1941; Chapman 1947; Mickalitis and Kutz 1949; Tryon 1952; Brown 1962). It has been estimated that approximately $60 \%$ of the land disturbed by mining between 1940 and 1971 was reclaimed in some fashion by industry (Limstrom 1960; Keys et al. 1971). This reclamation probably included backfilling and some type of tree or grass planting.

Through natural reclamation, many of these old partially reclaimed mine sites and even the unreclaimed mined sites 


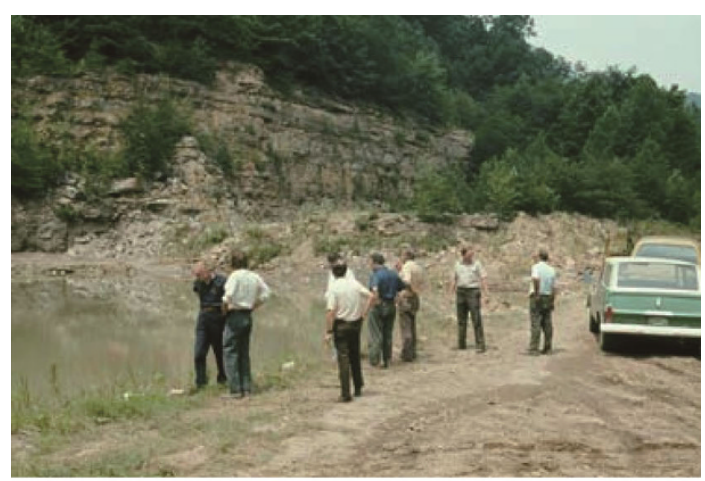

(a) Highwall on a West Virginia contour mine

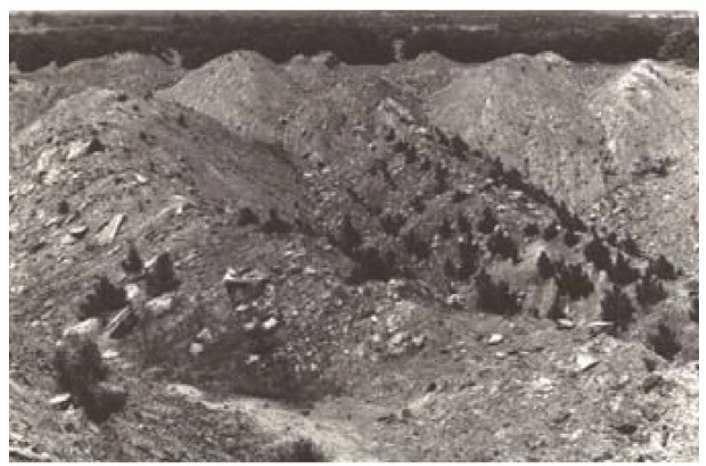

(b) Spoil ridges left by an Ohio Area mine

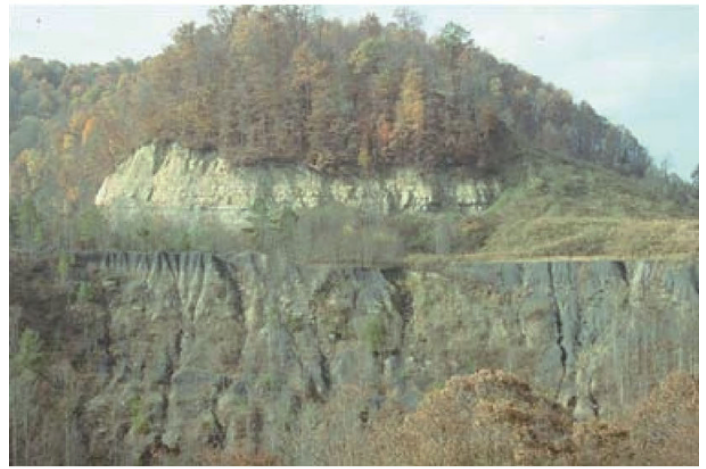

(c) An acidic ouslop and highwall left by a pre-law contour mining in Virginia

Fig. 4 Examples of lands in the Eastern USA coal mining areas left by early mining conducted when few or no laws existed to require reclamation

were subsequently colonized by native plants over time. Studies showed that, where soil materials were not highly acidic, compacted, or otherwise unfavorable to natural colonization, plant communities similar to those existing prior to mining sometimes developed on disturbed sites where no reclamation was done (Skousen et al. 2006). Similarly, where some reclamation was done with the planting of trees and herbaceous species, diverse plant communities also developed over time (Gorman et al. 2001; Skousen et al. 1990). In many cases, areas mined more than $40-50$ years ago that did not disturb highly acidic strata cannot be easily distinguished from undisturbed areas (Skousen et al. 2006).

As the demand for coal increased and surface mining became more prevalent, new techniques and larger equipment were developed to remove greater amounts of overburden (the rock materials overlying coal seams), producing more earthen material requiring replacement, reclamation, and revegetation.

\section{Laws and regulations of coal mine reclamation after 1977}

The Surface Mining Control and Reclamation Act (SMCRA) of 1977 caused a major change in reclamation practices and established federal control over coal mining, reclamation and environmental standards. The SMCRA established a federal-to-state oversight system, similar to other USA environmental legislation. Under this system, the federal government is able to assign enforcement of a federal law to a state agency, which allows the state to adapt regulations implementing the law to local conditions. If the federal agency grants the state authority to enforce the law, the state is said to have achieved "primacy." The state often establishes its own state-level law and regulations, which are specific to mining and reclamation conditions within the state, but the state laws cannot be less strict than the federal standards.

Under SMCRA, mining companies are required to prepare a permit application, which is a compilation of data concerning the characteristics of the potential mined site and a description of mining procedures and of strategies proposed to restore environmental conditions after mining. The data compiled in a surface mine permit in the USA include applicant identification, site analysis information, mining operation plans, environmental controls, and reclamation and revegetation procedures. Once approved by federal and state regulatory authorities, the mine permit is a contract between the regulatory authority and the company. The plans and procedures in the permit are then applied during mining to remove the coal and restore the site to a designated post-mining land use. Inspectors track the progress of the operation to ensure compliance with the permit conditions. If an operator does not comply with permit conditions, the inspector can stop the mining until the operator complies.

While a variety of information and data are required for the permit, six areas are of critical importance to reclaiming the site to a suitable condition after mining: (1) identification of pre-mining ecosystems, cultural resources, land use, and soils; (2) determination of overburden quality and subsequent placement during reclamation; (3) analysis of water quantity and quality before and after mining; (4) 
regrading and replacement of topsoil; (5) preparation of soil and selection of appropriate plant species for revegetation; and (6) the development of the designated postmining land use.

\subsection{Pre-mining ecosystem status, cultural resources, land use and soil information}

The permit application must include maps and information describing vegetation and plant communities present at the site (30 CFR 779.19). Such information will generally require a vegetation survey of the site. If any endangered or threatened plant or animal species are known to occur in the area, special precautions are to be taken to locate and identify these species.

The permit application must also describe "cultural, historic and archaeological resources" present on the proposed permit or adjacent areas. This requirement implements SMCRA Section 507(b)(13), which requires that maps depict "all man-made features and significant known archaeological sites." Maps must contain land ownership and all buildings within one thousand feet of the permit boundary.

The permit application must include information concerning current land uses and soil capabilities (30 CFR 780.23, 30 CFR 779.21). This will include a map of soil resources on the site, delineated by productivity; a map of current land uses; and narrative description of current and historic uses of the land. The application will also describe the "capability" of the land to support various and potential uses, considering factors such as soil conditions, topography, and vegetative cover.

Where pre-mining land uses provide income potential, such as forestry or agriculture, the permit must contain supporting information describing the productive capability of the land. If the land has been managed for agricultural cropping, yield information maintained by the landowner should be provided or yield can be based on current data from the U.S. Department of Agriculture, State agricultural universities, or appropriate State natural resource or agricultural agencies (30 CFR 780.23). This requirement can often be satisfied by referring to a county soil survey, such as those prepared by the U.S. Natural Resource Conservation Service (NRCS 2011) in partnership with state agricultural universities and agencies. County soil surveys include soil maps of county or multi-county regional areas and information concerning productive capability of soils located in such areas. Identifying the soil types overlying the proposed permit area can aid in providing this information. This land capability information is critical to the provision that reclamation shall "restore the land affected to a condition capable of supporting the uses which it was capable of supporting prior to any mining, or higher or better uses of which there is reasonable likelihood..." (SMCRA Section 515(b)(2)).

\subsection{Overburden quality and geology}

Permit applicants are required to describe locations of where borings from the surface to below the deepest level of disturbance will be taken, and to submit results of those borings with the permit application (30 CFR 780.22). The information must determine the rock types and thicknesses of each layer. This information will allow the applicant to characterize both the materials to be disturbed that will make up the filled mine area.

Samples from each stratum must be analyzed to evaluate the properties that will affect its use in reclamation, primarily acid generation and/or neutralization capacity via acid-base accounting. These analyses should identify "toxic" strata with potential to produce acidic drainage so that these materials may be managed in a manner that either isolates them from water flows or mixes (or "blends") them with offsetting alkaline materials. If acidic materials are to be managed by blending, the offsetting alkaline strata should also be identified. If a given stratum is being proposed for use as a topsoil substitute, that stratum should be identified in the geologic information.

\subsection{Surface and ground water quantity and quality}

The location, nature, name, quantity, and quality of all surface water bodies located on the permit area must be noted on maps. These include streams, lakes, impoundments, and springs, and any other sources of water and discharges from the permit area. Monitoring data are required for each water body and usually require one year of at least monthly data collection to establish baseline conditions. Water flow rates must be determined monthly and water quality data usually include $\mathrm{pH}$, iron and manganese concentrations, and total suspended solids. Other parameters may be required based on the local conditions and laws.

\subsection{Regrading and replacement of topsoil}

An important provision in SMCRA for re-establishment of a suitable post-mining land use requires the land to be returned to its "approximate original contour" $(515(\mathrm{~b})(3))$ and to place spoil on the reclaimed mine site to assure mass stability (515(b)(22)). The term "approximate" was used because rock materials expand or swell from $10 \%$ to $30 \%$ after blasting and therefore the reclaimed area may have slightly different land forms and elevations than what existed prior to mining. Variances can be granted where the post-mining land use may require a different or modified landscape to meet its objective. 
For certain post-mining land uses such as airports, shopping centers, and industrial parks, compaction of surface materials is necessary. Support features such as runways, roadways, and parking areas require that both subsurface and surface materials be compacted. Compaction of fill materials can prevent excessive downward movements of the land surface due to subsidence and settlement. Excessive downward movement of land surfaces supporting structures will distort structures, rendering them unusable or requiring expensive repair.

Most post-mining land uses require successful establishment of plant materials. In order to achieve that, reclamation procedures must provide a soil medium that enhances their survival and growth. Excessive compaction of soils will slow and limit the development of plants necessary for the post-mining land use. Compaction effects are more severe for woody plants that require deeper soils, such as forest trees, than for grasses with root systems that are confined to the upper $15 \mathrm{~cm}$ or so of soil materials. Soil compaction also limits movement of water and air, which are required for healthy root growth within the soil.

Smaller dozers will exert less compaction than larger dozers and should be used for spreading and grading of topsoil as a means of avoiding soil compaction during reclamation. Surface materials should be spread and graded when in a relatively dry condition. When establishing forest trees as a post-mining land use, the best way to limit soil compaction is to avoid using any equipment that runs over the finished surface. An excavator, for example, can level spoil piles left by haulers, but would not be capable of smoothing surface soils as needed for agricultural hay lands or areas surrounding building structures.

Performance standards in SMCRA (Sections 515(b)(5) and (6)) require that all topsoil be salvaged. The term "soil" refers to all surface soil material to a depth of broken bedrock that can be removed with a dozer. Soil includes the O, A, E, B, C, and R soil horizons, and should include soil organic matter and plant materials. If the topsoil is less than $15 \mathrm{~cm}$ thick (6 inches) thick and a topsoil substitute has not been approved, regulations require the operator to remove the topsoil along with a suitable amount of unconsolidated material immediately below the topsoil ( $\mathrm{C}$ horizon) and treat the mixture as topsoil. Topsoil should be redistributed immediately unless it is impractical, in which case it should be stockpiled, segregated, and protected. When redistributed, the soil must achieve "an approximately uniform, stable thickness," although that thickness may be varied to meet revegetation goals; and should be consistent with the postmining land use, contours, and drainage systems. The soil redistribution operation should prevent excess compaction.
Regulations allow selected overburden materials to be substituted for topsoil or used as a soil supplement if the operator demonstrates that the substitute material is equally or more suitable for sustaining vegetation. If a substitute material is approved for use, it should be handled and managed like topsoil.

Replacement of native topsoil on mine sites, especially for uses such as forest, is important for three reasons. First, viable seeds and propagules contained in the soil provide a seed bank to enable restoration of native species. Second, organic matter in the native soil contains essential soil nutrients for plant growth. Third, soil-dwelling animals and microorganisms in the native soil aid in providing and cycling nutrients for plants, create channels for air and water movement, and promote favorable hydrologic properties. Soil should be considered a "living resource" and re-spread immediately when possible.

Special soil handling requirements are applied when mining operations occur on prime farmland. Prime farmlands are areas with soils that meet specific criteria and are highly productive for agriculture. If prime farmland is to be disturbed by mining, special SMCRA requirements apply (Dunker and Barnhisel 2000). Such areas must be identified in the mining permit by soil surveys or agricultural agencies, and a plan to restore the agricultural use and productivity for such areas is required. The restoration plan must include reclamation practices to restore "equivalent or higher levels of yield as non-mined prime farmland in the surrounding area." The restoration plan must also describe segregation, storage (if necessary), and replacement of individual soil horizons ( $\mathrm{A}, \mathrm{B}$, and $\mathrm{C}$ horizons) from the prime farmland area. Restoration of productivity is required within 10 years after soil replacement.

\subsection{Plant species selection for revegetation}

Under SMCRA, revegetation standards are driven by postmining land use considerations. However, most mine sites are prepared for specific post-mining land uses (i.e. uses that are dependent on the type of vegetation established). On such areas, SMCRA Section 515(b)(19) requires operators to "establish on the regraded areas a diverse, effective, and permanent vegetative cover of the same seasonal variety native to the area of land to be affected and capable of self-regeneration and plant succession at least equal in extent of cover to the natural vegetation...." SMCRA performance standards also require the mine operator to "assume the responsibility for successful revegetation" for the SMCRA regulatory period "after the last year of augmented seeding, fertilizing, irrigation, or other work" (Section 515(b)(19)). The SMCRA regulatory period is generally 5 years, unless average annual rainfall 
is 26 inches or less (where the regulatory period is 10 years).

Federal regulations describing revegetation requirements are fairly general (30 CFR 816.111-117), leaving specifics such as species selection to the states. General requirements include statements that revegetation should be "diverse, effective, and permanent" and "comprised of species native to the area" unless introduced species are "desirable and necessary to achieve the approved postmining land use." The post-mining vegetation should be "at least equal in extent of cover to the natural vegetation," "capable of stabilizing the soil surface, capable of selfregeneration and plant succession, and compatible with both the post-mining land use and local ecosystems" (30 CFR 816.111). More specific regulatory criteria for determining if revegetated lands satisfy SMCRA revegetation requirements are generally developed by the states but within guidelines established by federal regulations (30 CFR 816.117).

\subsection{Development of a desirable post-mining land use}

SMCRA performance standards require the mine operator to "restore the land affected to a condition capable of supporting the uses which it was capable of supporting prior to any mining, or higher or better uses of which there is reasonable likelihood" (Section 515(b)(2)). The postmining land use must be designated in the permit, so the mine operator will know the post-mining land use prior to mining and reclamation operations. Such knowledge can be helpful to mining operations since reclamation, although often considered to be the last step in the mining process, must actually be integrated earlier in the mining process if post-mining land uses are to be achieved. Commercial, residential, and industrial land uses, for example, will often require that a specific landform, different from the original topography, be created by the mining operation and may require different materials and compaction of mine fills intended to support developed areas.

A variety of post-mining land use designations are available such as rangeland (in the Western USA), prime farmland (in Midwestern USA areas where coal underlies prime farmland), unmanaged or commercial forest (in the Eastern and Midwestern USA), hay land, pastureland, and developed land uses such as commercial land, residential land, or industrial sites. In some cases, mined lands have been reclaimed to serve public uses, such as parklands, hunting and fishing areas, and recreational areas such as parks and ball fields.

Decisions concerning which post-mining land uses are "higher or better" than a given pre-mining use are matters of regulatory interpretation. For example, post-mining land uses that require surface development, such as industrial, commercial, and residential, are generally considered to be "higher and better" than extensive land uses such as agriculture, forestry, or range land. Land uses requiring management, such as cropland, hay land, or pasture, are often considered "higher and better" than post-mining land uses that do not require management, such as range land or forestry.

If a "higher and better" post-mining land use is proposed, regulations require "appropriate assurances" that such land use is attainable and compatible with the surrounding land uses. For example, permit applications for developed land uses are generally required to document accessibility of utilities and suitable road access. Permit applications for mines that seek to alter land contours for the purpose of achieving a "higher and better" post-mining land use face additional requirements to document the feasibility of the proposed post-mining use. Permit applications that propose agricultural land uses, such as hay land or pasture, to replace natural ecosystems such as unmanaged range land or forest must provide statements from landowners that the land will be used for that purpose.

Regulatory authorities vary in their assessment of postmining land use achievement, especially when the postmining land use requires development. If the development is achieved within the SMCRA regulatory period, the construction process would often satisfy regulatory requirements concerning post-mining land use. If a postmining land use like building site development is not actually achieved, regulatory interpretations would vary. In Virginia, for example, a mine site with an industrial postmining land use that does not result in actual industrial development may be approved for bond release, if site configuration, access, underlying spoil stability, and other characteristics have been created that make it suitable for eventual industrial development (Zipper and Yates 2009). Among land uses, those intended to support livestock grazing (e.g. pasture land) are often assessed on whether or not grazing animals are supported by the forage plants established during reclamation. Agricultural cropping land uses, such as hay land and crop land and including "prime farmland," are often assessed for compliance based on a comparison of measured post-mining yields to those recorded prior to mining on those same lands, or on nearby reference areas with similar soils and site conditions. Forested post-mining land uses are generally assessed for SMCRA compliance based on counts of living stems at the conclusion of the bond-release period or a specified amount of tree height growth per year. Federal regulations contain minimum criteria for establishing success standards for extensive land uses (30 CFR 816.117), but state authorities also establish specific standards. 


\section{Compliance with laws and regulations}

The foregoing discussion described performance standards required in SMCRA. When such standards are not met, regulatory authorities (either federal or state) have three primary mechanisms to enforce compliance.

(1) Fines Enforcing agencies have the power to impose fines on mining companies if performance standards are not met as described in the permit.

(2) Performance bond A performance bond is a sum of money sufficient to complete reclamation, if the company were to avoid its obligations. The mining firm must post a performance bond before mining begins. If the company was to produce a mining disturbance but failed to reclaim the land in a manner that satisfies permit requirements, the regulatory agency would use the performance-bond funds to pay for reclamation. Performance bonds may be posted as cash deposits by the mining firm itself, or the mining firm may work with a surety or insurance company to satisfy the bonding requirements. Some states operate alternative bonding systems, some of which are known as "bond pools," which reduce the cost and capital requirements of bonding; participation in such alternative systems is often limited to mining firms that have compiled a history of satisfactory reclamation performance.

(3) Permit blocking If a company fails to fulfill its mine reclamation obligations under the SMCRA, neither that company nor any of its principal owners are allowed to take out any more mining permits until those reclamation obligations have been met.

\section{Early SMCRA reclamation practices}

During SMCRA's early years, regulatory authorities encouraged grading and smoothing of reclaimed land, and rapid establishment of grasses and legumes (Plass 1982; Torbert and Burger 2000; Angel et al. 2005). Plant species commonly used for revegetation were agricultural forages, such as fescue grasses (Festuca surfaces spp.) and clovers (Trifolium spp.), and were often chosen because they satisfied the major reclamation objectives as perceived by regulators at the time. These forage species stabilized the surface and controlled soil erosion; established quickly; and enabled a quick economic return to land owners who used the post-mining lands for hay production or livestock grazing; were inexpensive and easy to establish; and were considered as aesthetically pleasing (Boyce 1999). This reclamation procedure was often described in SMCRA permits as a hay land or pasture post-mining land uses.
These post-mining land uses were selected and established on $80 \%$ to $90 \%$ of the land reclaimed during the early years of SMCRA (early 1980s and through the 1990s). While much of the land was used by landowners as prescribed, many other lands reclaimed as hay land or pasture were not used by landowners for that purpose. Such lands were often left in an unused and unmanaged condition. When such lands were established with soils similar to the natural area, woody species would gradually invade by natural secondary succession if given sufficient time, especially where the reclaimed site was closely surrounded by native forest (Skousen et al. 2006). The succession process progresses through a series of pioneer and earlysuccessional tree species such as red maple, black locust, black birch (Betula lenta L.), black cherry (Prunus serotina Ehrh.), autumn olive, crabapple (Prunus coronaria L.) and hawthorn (Crataegus spp.). Gradually, ash (Fraxinus spp.), yellow poplar, sugar maple (Acer saccharum Marsh.), oak, hickory (Carya spp.), and other mid- to late-successional trees can become established in the understory and replace some of the early-successional trees. However, a more common outcome was for such lands to be left with compacted soils constructed with mine spoils that differed chemically from native soils and covered with dense herbaceous vegetation. Such lands did not return to native forest cover naturally even within several decades after mining (Angel et al. 2005; Zipper et al. 2011a). Soil properties, vegetation established through reclamation, aspect, subsequent disturbance, local climate/weather patterns and wildlife are factors that influence the eventual plant community on unmanaged reclaimed mine lands.

Establishment of commercially valuable forest by natural succession on lands reclaimed using conventional post-SMCRA reclamation is extremely slow even where soils are favorable, often requiring several decades to develop (Zipper et al. 2011a). Non-native invasive plant species often become established on such areas (Zipper et al. 2011a). Natural plant succession on reclaimed land with compacted soils and heavy ground cover is said to be "arrested" and such sites can remain as grass-shrub dominated "scrublands" for decades or longer (Groninger et al. 2007). Such a condition is not desirable for landowners who would like to eventually harvest commercial lumber from the site.

\section{Post-mining land use designations and procedures}

\subsection{Prime farmland-agriculture}

Federal and state regulatory agencies have standards in place to regulate prime farmland mining and reclamation (Dunker et al. 2012; Dunker and Barnhisel 2000). As a 

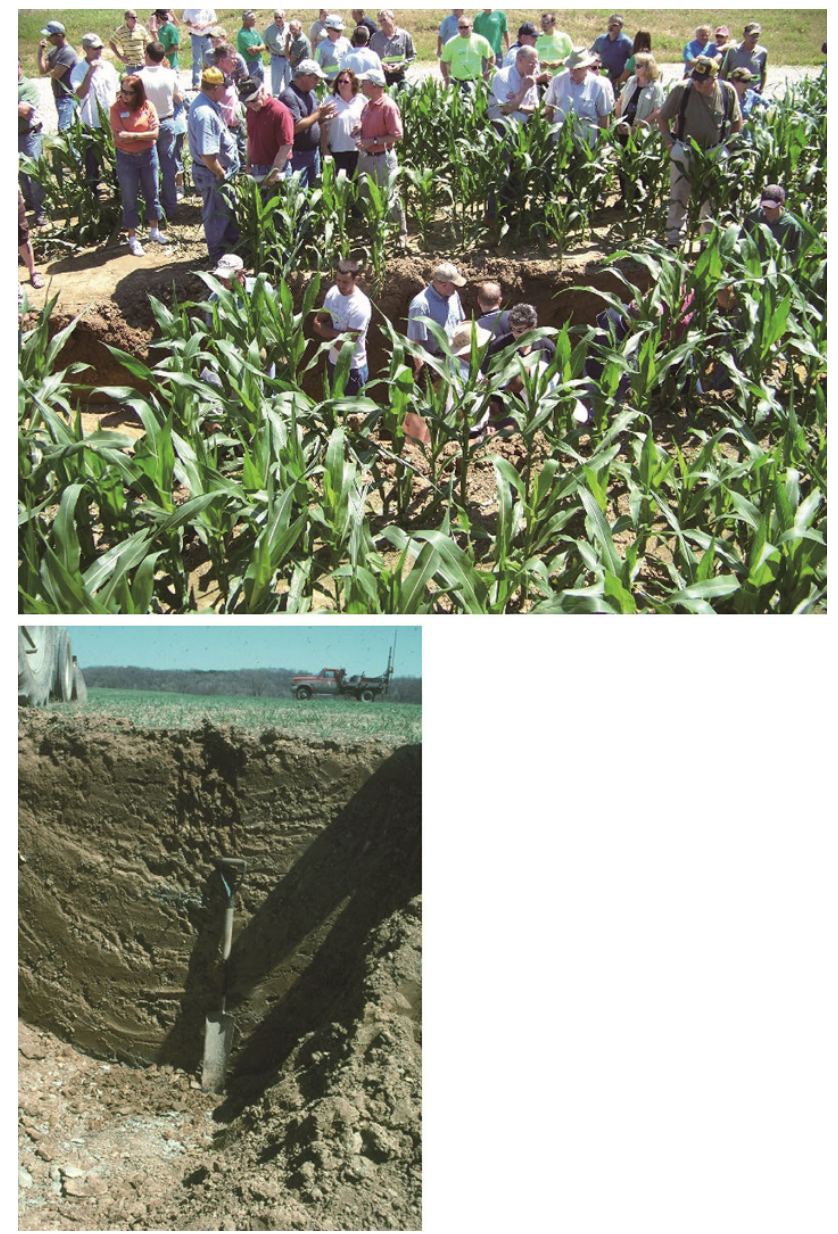

Fig. 5 Reclamation of prime farmland must replace the soil horizons and produce yields equal to yields on adjacent undisturbed sites under the same management

result, most prime farmland reclamation includes separate removal of $\mathrm{A} / \mathrm{E}, \mathrm{B}$, and $\mathrm{C}$ soil horizons, with separate storage piles if they are not moved directly to reclamation areas. Soil replacement is done in the correct order and with similar depths (Fig. 5). Because of the legal requirement to restore agricultural productivity on prime farmlands, it is essential that soils be replaced in a manner that does not cause excessive soil compaction, when possible. Otherwise, compacted soils should be loosened using physical means. Lime, fertilizer, and mulch should be applied as needed to establish vegetation, and vegetation should be established as quickly as possible.

\subsection{Hay land and pasture}

Many mined areas in the eastern USA are capable of supporting highly productive forage crops for livestock if reclaimed and managed for that purpose (Fig. 6; Ditsch and Collins 2000). Even mined lands in western areas that

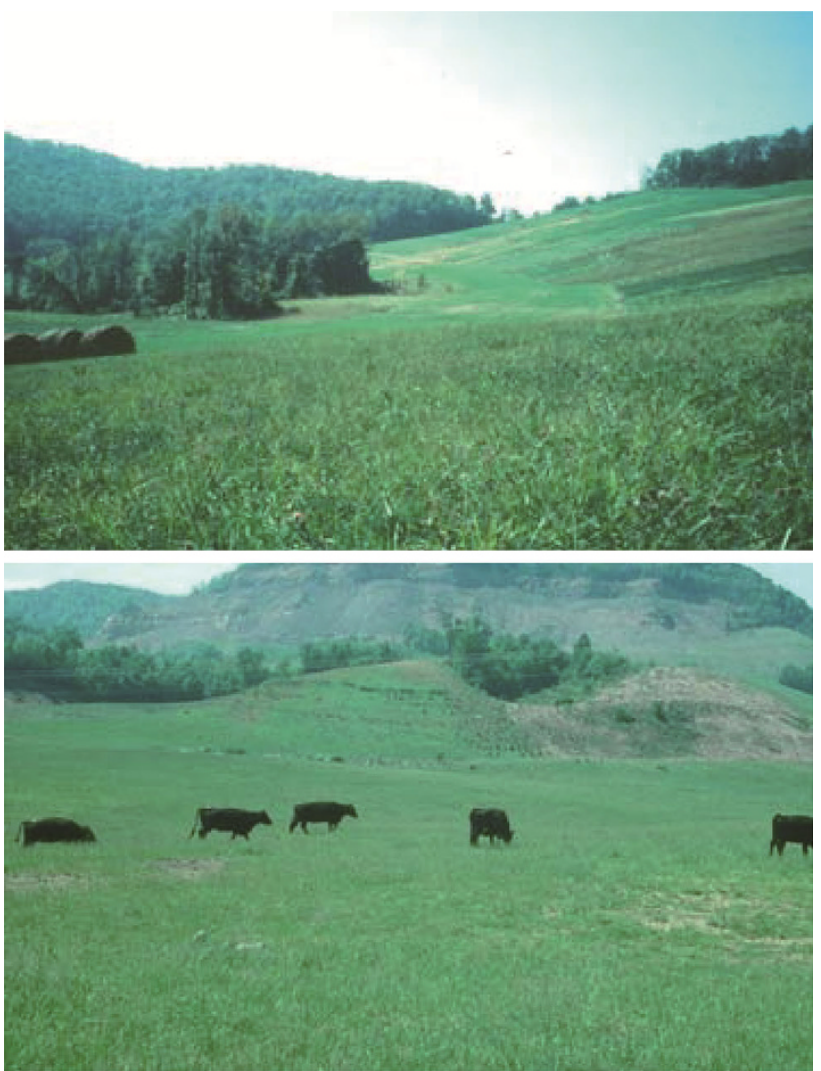

Fig. 6 Hay land and pasture post-mining land uses on coal mined lands reclaimed under SMCRA

receive less rainfall can serve as livestock pastures if suitably reclaimed (Reeder and McGinnies 1989; Ries and Nilson 2000; Schuman et al. 1985). Use of topsoil for reclamation can enhance the land's capability to produce forage for hay and livestock (Sutton and Hall 1987). As with agriculture on natural soils, periodic inputs of lime and fertilizer are necessary periodically to maintain the quantity and quality of the forage on mined land pastures (Sutton and Hall 1987). Many of the grass and legume species commonly grown on non-mined pastures also can be established on mine soils (Ditsch and Collins 2000).

In order to be suitable for hay land and pasture uses, reclaimed mined lands should have smooth soil surfaces, soil materials that are well suited for agricultural grass and legume species, and moderate slopes. Because of operating requirements of managing and harvesting equipment, slopes of $15 \%$ or less are generally preferred for hay lands. While pasture land can be placed on steeper areas, slope limitations still apply due to the operational needs of agricultural equipment necessary for effective pasture management such as fertilization, liming, over-seeding, and undesirable plant control. When establishing pastures on mined areas, it is essential to provide a water source. One study has found that cattle utilize pastures readily if they are within $240 \mathrm{~m}$ of a 
Table 1 Common hay and pasture species for use on Eastern USA surface mine sites ${ }^{\mathrm{a}}$

\begin{tabular}{|c|c|c|c|c|}
\hline Common name & Scientific name & Soil $\mathrm{pH}$ range & Wet soil ${ }^{b}$ & Comment \\
\hline \multicolumn{5}{|l|}{ Grasses } \\
\hline Orchardgrass & Dactylis glomerata & $4.5-7.5$ & $\mathrm{P}$ & Long-lived \\
\hline Tall fescue & Festuca arundinacea & $5.0-8.0$ & $\mathrm{G}$ & $\begin{array}{l}\text { Good species for most mine soils. } \\
\text { Use endophyte-resistant varieties }\end{array}$ \\
\hline Perennial ryegrass & Lolium perenne & $5.0-7.5$ & $\mathrm{P}$ & Short-lived \\
\hline Switchgrass & Panicum virgatum & $4.1-7.6$ & $\mathrm{E}$ & Slow to establish but productive in warm season \\
\hline Timothy & Phleum pratense & $4.5-8.0$ & $\mathrm{P}$ & $\begin{array}{l}\text { Good quality forage but does not tolerate } \\
\text { heavy grazing. Requires good fertility }\end{array}$ \\
\hline \multicolumn{5}{|l|}{ Legumes } \\
\hline Birdsfoot trefoil & Lotus corniculatus & $5.0-7.5$ & $\mathrm{G}$ & Tolerates acidic soils. \\
\hline Alfalfa & Medicago sativa & $6.5-7.5$ & $\mathrm{P}$ & Requires deep soil, good drainage, $\mathrm{pH}>6$, adequate soil $\mathrm{P}$ \\
\hline Yellow sweetclover & Melilotus officinalis & $5.5-7.0$ & $\mathrm{~F}$ & More drought tolerant and competitive than white clover \\
\hline Alsike clover & Trifolium hybridum & $5.0-7.5$ & $\mathrm{~F}$ & More tolerant of moist, acidic soils than other clovers \\
\hline Red clover & Trifolium pratense & $5.5-7.0$ & $\mathrm{~F}$ & Requires adequate soil $\mathrm{P}$ \\
\hline White clover, Ladino clover & Trifolium repens & $6.0-7.0$ & $\mathrm{P}$ & Good for erosion control, requires adequate $\mathrm{P}$ and $\mathrm{Ca}$ \\
\hline
\end{tabular}

${ }^{a}$ For further information, see Ditsch et al. (2006) and Skousen and Zipper (2010)

b Tolerance of wet soil conditions: $E$ excellent, $G$ good, $F$ fair, $P$ poor

water source; but pastures beyond that distance are not be well utilized (Ditsch et al. 2006).

Soil and spoil materials used to construct pasture soils should be moderate to neutral in $\mathrm{pH}$, should have at least $30 \%$ silts and clays, and should not have excessive rock contents. Many pasture plant species prefer soil $\mathrm{pH}$ in the 6.0 to 7.0 range, although slightly more acidic materials $(>5.5)$ can be used if the mine soils are limed. The presence of nitrogen-fixing legume species, such as clovers, is essential to nutritious pasture vegetation; most pasture legumes do not persist if adequate soil $\mathrm{pH}$ is not maintained. Mine soils being prepared for hay and pasture use should be graded smoothly under dry conditions and using small equipment so as to minimize soil compaction. Such areas can be seeded with a mixture of pasture grasses and legumes area (see example, Table 1). At least $112 \mathrm{~kg} \mathrm{~N}$ and $120 \mathrm{~kg}$ per ha $\mathrm{P}$ (equivalent to $275 \mathrm{~kg}$ per ha of $\mathrm{P}_{2} \mathrm{O}_{5}$ ) are recommended to provide the fertility that is necessary for productive pasture.

\subsection{Forest}

Forested post-mining land uses can produce economic benefits for landowners, including harvestable timber when sufficient productivity is restored. Reestablishment of forested vegetation on mine sites also creates societal value, as those growing forests produce "ecosystem services" by storing carbon, protecting water quality, and regulating water quantity to reduce high flows and flooding (Zipper et al. 2011b).

Because conventional reclamation practices under SMCRA in Eastern USA have not enabled forest tree species to reestablish, a new reclamation method called the Forestry Reclamation Approach (FRA) has been developed (Burger et al. 2005; Zipper et al. 2011b). The FRA is intended for use when re-establishing forest vegetation on Eastern USA mine sites and it is being widely applied by coal mine operators (Fig. 7). The FRA is comprised of five steps.

FRA Step 1 Create a suitable rooting medium for good tree growth that is no less than four feet deep and comprised of topsoil, weathered sandstone, and/or the best available material.

When available, native soil material should be salvaged and re-spread for reforestation. The salvaged materials should include organic materials from the original forest soil (roots, stumps, organic debris, etc.); these materials should be re-spread as soon as possible after excavation so as to maintain the resident biota in a living state. Weathered non-pyritic overburden materials can also be used (Zipper et al. 2013). Ensuring that soil materials have $\mathrm{pH}$ suitable for the trees being planted is essential to those trees' successful re-establishment.

FRA step 2 Loosely grade the topsoil or topsoil substitutes established in step one to create a non-compacted soil growth medium.

Historically in the Eastern USA, high soil density has hindered forest tree establishment and growth. Soil compaction during reclamation can be avoided by minimizing grading, by restricting grading during dry soil conditions, and by using small equipment (Sweigard et al. 2007). The 


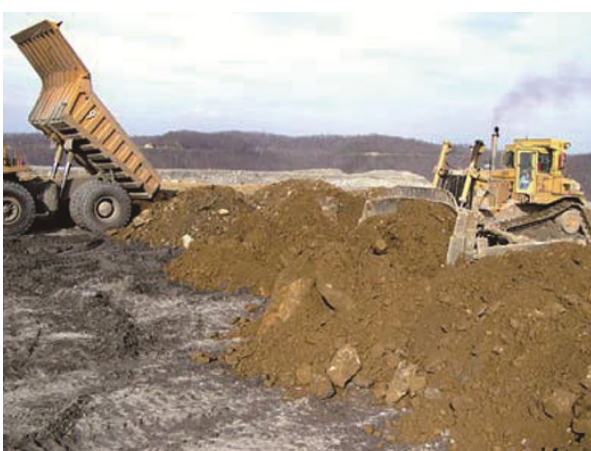

(a) Placement of brown topsoil up to $1.5 \mathrm{~m}$ in depth

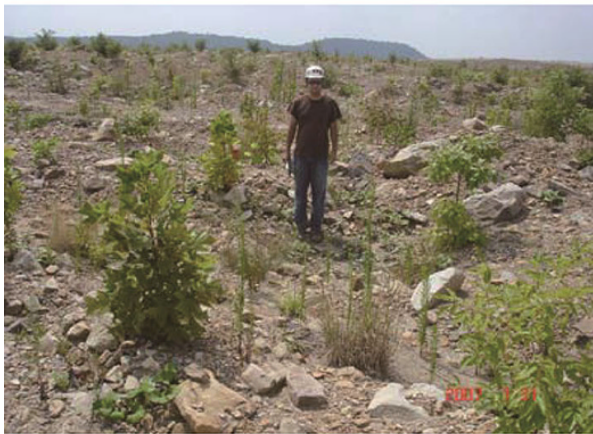

(b) Tree growth after planting on such sites 2 years

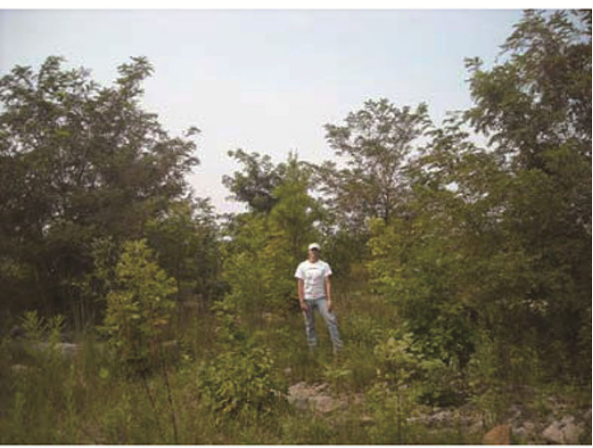

(c) Tree growth after planting on such sites 6 years

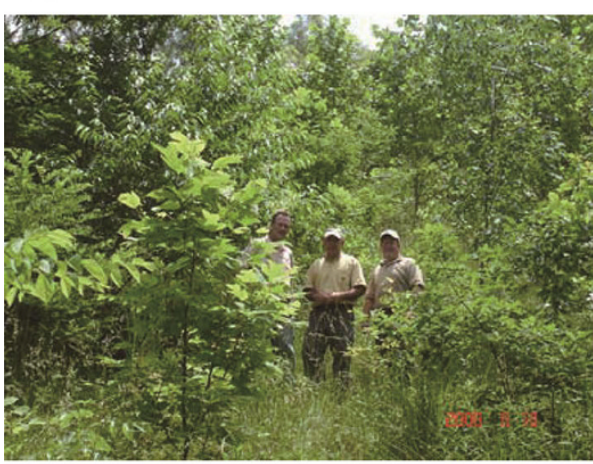

(d) Tree growth on such sites 15 years

Fig. 7 The Forestry Reclamation Approach emphasizes the placement of brown topsoil up to $1.5 \mathrm{~m}$ in depth with little to now compaction

rough soil surface left by loose grading encourages water infiltration and provides little resistance to root growth, aiding forest reestablishment. Loose soils also aid
Table 2 Example of a seeding and fertilizer application for FRA reclamation on eastern USA mine sites with soil properties that are suitable for re-establishing forest vegetation

\begin{tabular}{llc}
\hline Common name & Scientific name & $\begin{array}{l}\text { Rate } \\
(\mathrm{kg} / \mathrm{ha})\end{array}$ \\
\hline $\begin{array}{l}\text { Perennial grasses } \\
\text { Perennial ryegrass }\end{array}$ & $\begin{array}{l}\text { Lolium perenne } \\
\text { Orchardgrass } \\
\quad(\text { steep slopes only) }\end{array}$ & 11 \\
$\quad$ Timothy & Phleum pretense & 6 \\
Annual grasses & & \\
$\quad \begin{array}{l}\text { Annual ryegrass, or } \\
\text { Foxtail millet }\end{array}$ & $\begin{array}{l}\text { Lolium multiflorum } \\
\text { Legumes (with inoculant) } \\
\text { Birdsfoot trefoil }\end{array}$ & 28 \\
Ladino or white clover & $\begin{array}{l}\text { Lotus corniculatus } \\
\text { Trifolium repens }\end{array}$ & 34 \\
\hline
\end{tabular}

These rates are intended to achieve $>80 \%$ ground cover after 2 years. Species and rates may be varied in response to local conditions (adapted from Burger et al. 2009)

establishment of "volunteer" plant species that may enter the site as seeds carried by wind or wildlife.

FRA step 3 Use less competitive ground covers that are compatible with growing trees.

Herbaceous vegetation of a type that will minimize competition with tree seedlings can be seeded to provide erosion control (Burger et al. 2009). Excessive competition by erosion-control groundcover will hinder the planted trees' survival and growth. Traditional groundcovers, with fast-growing grasses and legumes, should not be used when reestablishing forest trees on mine sites. Seeding with "tree compatible" erosion-control mixes, comprised of species that are low in stature and in water and nutrient demands, is recommended (Table 2). These mixes are typically applied at relatively low seeding rates and with relatively low rates of $\mathrm{N}$ fertilizer (typically $55-85 \mathrm{~kg} / \mathrm{ha}$ ). Trees should be planted before herbaceous seeding mixes are applied, when possible, or shortly thereafter otherwise.

FRA step 4 Plant two types of trees - early successional species for wildlife and soil stability, and commercially valuable crop trees.

Crop trees are species that grow in the region's native forests and can produce saleable timber products (Table 3 ). Early successional trees are of species that can establish and grow quickly. Early successional trees can also be selected to add organic matter to the soil and to attract seed-carrying wildlife. It is also desirable to plant some tree species that fix atmospheric nitrogen, when such species are compatible with crop trees. On eastern USA mine 
Table 3 Tree species that are commonly planted on coal surface mines in eastern USA ${ }^{\mathrm{a}}$

\begin{tabular}{|c|c|c|}
\hline Common name & Scientific name & Comment \\
\hline \multicolumn{3}{|l|}{ Nurse trees } \\
\hline Black locust & Robinia psuedoacacia & Fast-growing nitrogen fixing trees \\
\hline Bristly locust & Robinia hispida & Nitrogen fixer for moist sites \\
\hline Dogwood & Cornus sp. & Understory species; produce food for wildlife \\
\hline Eastern redbud & Cercis canadensis & Understory species; produces food for wildlife \\
\hline Eastern white pine & Pinus strobus & Provides winter shelter for wildlife \\
\hline Red mulberry bra & Morus ru & Understory species; produces food for wildlife \\
\hline Shagbark hickory & Carya ovata & Provides habitat for Indiana Bat \\
\hline \multicolumn{3}{|l|}{ Crop trees } \\
\hline American sycamore & Platanus occidentalis & For wet soils and riparian plantings \\
\hline Black cherry & Prunus serotina & For cool climates and high elevations \\
\hline Black oak & Quercus velutina & For dry sites \\
\hline Black willow & Salix nigra & For riparian plantings \\
\hline Chestnut oak & Quercus prinus & For dry sites \\
\hline Northern red oak & Quercus rubra & For moist sites \\
\hline River birch & Betula nigra & For riparian plantings \\
\hline Scarlet oak & Quercus coccinea & For dry sites \\
\hline Sugar maple & Acer saccharum & For moist sites \\
\hline Sweetgum & Liquidambar styraciflua & For riparian plantings \\
\hline White oak & Quercus alba & For a range of site types \\
\hline Yellow poplar & Liriodendron tulipifera & For fine textured soils in lower-slope positions \\
\hline
\end{tabular}

${ }^{\mathrm{a}}$ For further details, and for information on additional species, see Davis et al. (2012)

sites, trees of multiple species are generally planted at combined rates ranging from 1,250 to 1,700 stems per hectare (Davis et al. 2012). Current recommendations are to use only species that are native to the local area.

FRA Step 5 Use proper tree planting techniques.

Proper tree planting must be employed if the planted trees are to have the potential to survive and grow (Davis et al. 2010). Such techniques require appropriate care of tree seedlings, to prevent them from becoming heated and dried prior to planting, and excavation of a planting hole that is adequate for the tree's root system.

Forests in the Eastern USA host numerous plant species, but few of those species are re-established during reclamation by seeding and planting. When favorable soil properties and other site conditions are reestablished during reclamation, the planted trees can act as catalysts in natural succession and development of a forest plant community. The techniques described above are intended to enable colonization by native plants whose seeds are carried by fauna and wind, as well as to establish key tree species by planting.

\subsection{Wildlife habitat}

Wildlife habitat post-mining land uses are prepared by Eastern USA operators using techniques similar to those used to prepare forest reclamation sites. A wildlife plan with plant species for specific wildlife-habitat purposes is developed. That plan usually includes shrubs and trees that provide food, shelter, or other resources needed by wildlife as primary components (Fig. 8). The plan may include blocks of vegetation intended for use by specific wildlife species. It may also include corridors of vegetation types that are suitable for wildlife that will enable their movement. Other parts of the mine site may be planted with plant species that are attractive to wildlife in random patterns. Wildlife habitat established through reclamation may also include specific habitat features such as wetlands or other water sources that will be utilized by wildlife. Methods for establishing wildlife habitat on Eastern USA coal mined sites are described by Wood et al. (2013).

\subsection{Biofuel crops}

Environmental challenges and costs of conventional energy sources, including fossil fuels, have increased demands for plant-based biomaterials that can burned to produce heat or generate electric power or converted to liquid fuels. The majority of the USA's plant-based liquid fuel demands are met by producing corn (Zea mays L.) on farm land and converting it to ethanol. But there are concerns with use of farm land to produce fuels in the face of rising national and 


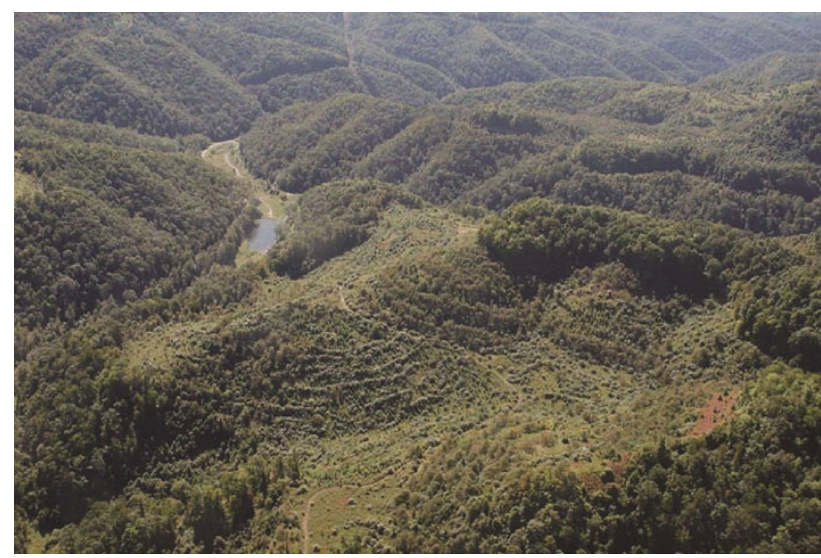

Fig. 8 Wildlife habitat designs include rows of shrubs and trees across the mine site to encourage wildlife movement across the area. The plant species also provide food and shelter
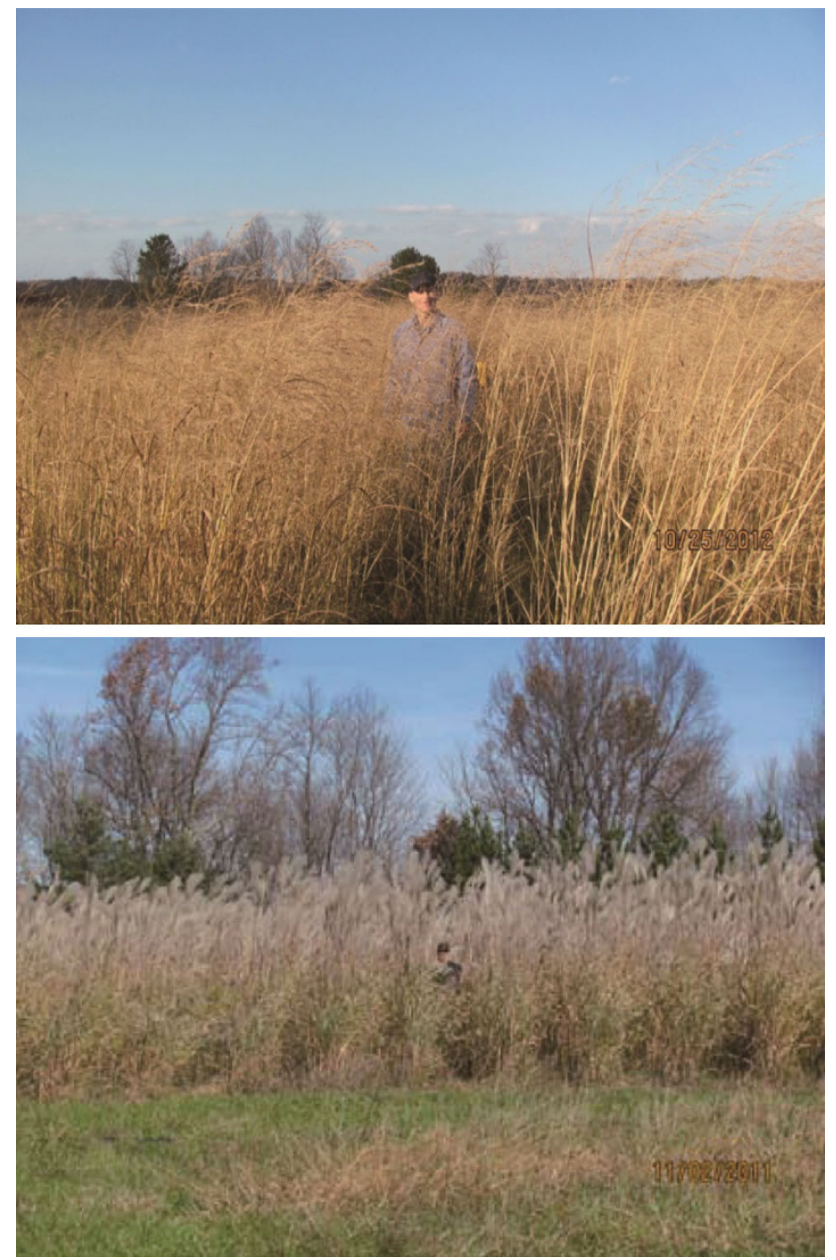

Fig. 9 Switchgrass and Miscanthus growth on surface mines on the Eastern USA surface mines

global food demands. Hence, researchers are examining other biofuel feedstock options. Many perennial herbaceous plants have been evaluated as sources for cellulosic materials to be converted to biofuels. Switchgrass (Panicum virgatum L.), a warm season perennial grass native to North America and commonly used as a conservation species, has been investigated extensively as a source of biofuel feedstock (Fike et al. 2006). Due to its high biomass production, adaptability, tolerance to adverse growing conditions and low input requirements, switchgrass has been termed "the model" cellulosic biofuel feedstock (Parrish and Fike 2005). Miscanthus giganteus is another high-yielding plant with potential to produce large quantities of biomass.

Growing switchgrass and other biofuel crops on surface mined lands with good soil properties could be a profitable and efficient post-mining land use. In addition, reclaimed lands with existing cool-season grasses and legumes, such as fescue and lespedeza, could be converted to production of biofuel crops.

Studies conducted on switchgrass grown on surface mines have shown biofuel production is achievable (Fig. 9). Switchgrass performance was more than $5 \mathrm{Mg} / \mathrm{ha}$ after the second year on a fertile mine soil in West Virginia (Keene and Skousen 2010), and more than $7 \mathrm{Mg} / \mathrm{ha}$ after 3 years (Marra et al. 2013). Miscanthus attained $15 \mathrm{Mg} / \mathrm{ha}$ on a reclaimed mine site in West Virginia after 2 years of growth (Skousen et al. 2013, 2014). These results demonstrate the potential opportunity of high yielding biomass crops as feed stocks for transportation fuels on mined lands.

It is also possible to employ woody crops as a means of producing biofuels on reclaimed mine sites. Species that have been documented as performing well on Appalachian mined areas include willow, hybrid poplar, American sycamore, and black locust (Brinks et al. 2011; Zipper et al. 2011c). Woody biofuel crops may prove advantageous, relative to herbaceous crops, on mined land sites with slopes or soils that would hinder operation of the agricultural equipment that is necessary for production of herbaceous crops such as switchgrass or Miscanthus.

Mined lands can be prepared for establishment of herbaceous biofuel crops using procedures described for hay land and pasture establishment, as stated above. Mined lands can be prepared for woody biofuel crops using procedures described for forest establishment, as stated above. However, in contrast to native hardwoods, hybrid poplars prefer soils in the $\mathrm{pH}$ range of 6.0-7.0.

\subsection{Developed land uses (industrial, commercial, residential)}

Eastern USA mined lands are in rare cases reclaimed to support residential, commercial, or industrial development. Although such reclamation is not common in eastern USA, such lands can be highly beneficial to local communities when they are developed successfully Surface stability is a critical factor affecting suitability of reclaimed mines for 

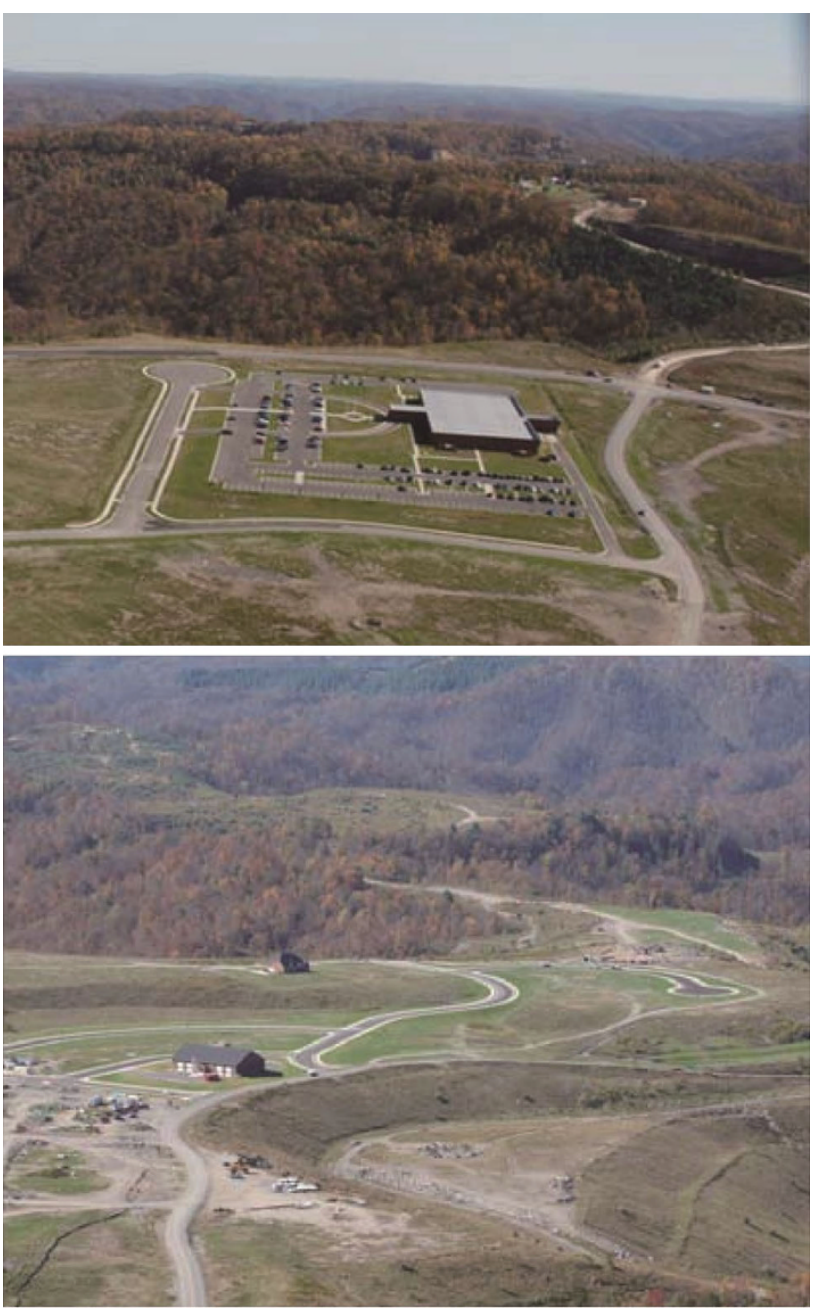

Fig. 10 Commercial and residential post-mining land uses must ensure stable land surfaces and no mass movement of materials for structures to be safe

industrial, commercial, and residential development. Other important factors include the reclaimed mine site's access to water, utilities, and waste disposal. Surface stability for the building development area can be achieved by using common-sense procedures that are well supported by engineering practice (Zipper and Winter 2009).

A building development area (building support "pad") should be located over flat benches when possible (Fig. 10). The pad should be constructed by placing spoil in lifts of controlled thickness and composition. Each lift should be constructed using a relatively uniform spoil material that is compacted in place. Lift thicknesses can vary based on engineering specifications considering both the nature of the spoil material and the level of compaction that is necessary to ensure sufficient surface stability for the post mining land use. The entire building support pad should be well drained.

These construction procedures are intended to minimize settlement of the mine spoil fill that supports the building development area, and to ensure that whatever settlement occurs is relatively slow and uniform over the entire building support area.

\section{Sustainable reclamation}

Sustainability is an essential concept for the mining industry. A common definition for sustainability is that advanced by the Brundtland Commission, which defined sustainable development as "development that meets the needs of the present without compromising the ability of future generations to meet their own needs." The concept of sustainable development has been embraced by the mining industry. In order for mining to be sustainable, "reclamation" must establish post-mining land and water conditions that will meet human needs.

Mined landscapes meet human needs when they support viable economic enterprises and other forms of community development. Mining also meets human needs when it reestablishes "ecosystem services," which are the functions and processes of natural ecosystems that are of value to human society.

The "sustainable mining" concept can also be extended to apply to mining enterprises. A continued ability to secure permits is essential to the mining business. An ability to execute reclamation practices cost effectively and in a manner that produces land and water resources to meet human needs essential to the sustainability of any mining business.

Open Access This article is distributed under the terms of the Creative Commons Attribution License which permits any use, distribution, and reproduction in any medium, provided the original author(s) and the source are credited.

\section{References}

ACSMP, Australian Centre for Sustainable Mining Practices (2011) A guide to leading practice sustainable development in mining. Leading practice sustainable development program. Australian Government, Department of Industry

Angel P, Davis V, Burger J, Graves D, Zipper C (2005) The Appalachian regional reforestation initiative. US Office of Surface Mining, Appalachian Regional Reforestation Initiative, Forest Reclamation Advisory Number 1 http://arri.osmre.gov/ FRA/Advisories/FRA_No.1.7-18-07.Revised.pdf

Ashby WC (2006) Reflections of a botanist on reclamation to trees. Reclamation Matters, Vol. 3, Issue 2, Fall 2006. American Soc. of Mining and Reclamation, Lexington

Boyce S (1999) Office of surface mining (OSM) revegetation team survey results. p. 31-35. In: Vories KC, Throgmorton D (ed) Proc. Of the Enhancement of Reforestation at Surface Coal Mines: Technical Interactive Forum, SIU, Carbondale. 23-24 Mar. 1999, USDI, OSM, Coal Res. Ctr., Southern Illinois Univ., Carbondale Brinks JS, Lhotka JM, Barton CD, Warner RC, Agouridis CT (2011) Effects of fertilization and irrigation on American sycamore and 
black locust planted on a reclaimed surface mine in Appalachia. For Ecol Manage 261:640-648

Brown JH (1962) Success of tree planting on strip-mined areas in West Virginia. West Virginia Agric. and For. Exp. Stn. Bull. 473. West Virginia University, Morgantown

Burger J, Graves D, Angel P, Davis V, Zipper C (2005) The forestry reclamation approach. US Office of Surface Mining, Appalachian Regional Reforestation Initiative, Forest Reclamation Advisory Number 2. http://arri.osmre.gov/FRA/Advisories/ FRA_No.2.7-18-07.Revised.pdf

Burger J, Davis V, Franklin J, Zipper C, Skousen J, Barton C, Angel P (2009) Tree-compatible groundcovers for reforestation and erosion control. US Office of Surface Mining, Appalachian Regional Reforestation Initiative, Forest Reclamation Advisory Number 6. http://arri.osmre.gov/FRA/Advisories/FRA_No.6.pdf

Chapman AG (1947) Rehabilitation of areas stripped for coal. USDA Forest Service Central States Forest Experiment Station Technical Paper 108. USDA Forest Service, Columbus

Davis V, Franklin J, Zipper C, Angel P (2010) Planting hardwood tree seedlings on reclaimed mine land in Appalachia. US Office of Surface Mining, Appalachian Regional Reforestation Initiative, Forest Reclamation Advisory Number 7. http://arri.osmre.gov/ FRA/Advisories/FRA_No.7_Feb.26.2010.pdf

Davis V, Burger J, Rathfon R, Zipper C, Miller C (2012) Selecting tree species for reforestation of Appalachian mined land. US Office of Surface Mining, Appalachian Regional Reforestation Initiative, Forest Reclamation Advisory Number 9. http://arri.osmre.gov/ FRA/Advisories/FRA_No.9_TreeSpeciesSelection.pdf

Ditsch DC, Collins M (2000) Reclamation considerations for pasture and hay lands receiving $66 \mathrm{~cm}$ or more precipitation annually. In: Barnhisel R, Darmody R, Daniels W (eds) Reclamation of drastically disturbed lands. Agronomy monograph, 41st edn. American Society of Agronomy, Madison, pp 241-271

Ditsch D, Teutsch C, Collins M, Whittier M, Rockett M, Zipper C, Johns J (2006) Managing livestock forage for beef cattle production on reclaimed surface-mined land. University of Kentucky Cooperative Extension Service Publication ID-157. http://www.prp.cses.vt.edu/UKY_id157.pdf

Drummond M, Loveland TR (2010) Land-use pressure and a transition to forest-cover loss in the eastern United States. Bioscience 60:286-298

Dunker R, Barnhisel R (2000) Cropland reclamation. In: Barnhisel R, Darmody R, Daniels W (eds) Reclamation of drastically disturbed lands. Agronomy monograph, vol 41. American Society of Agronomy, Madison, pp 323-369

Dunker R, Bullock D, Bollero G, Armstrong K (2012) A system to evaluate prime farmland proclamation success based on spatial soil properties. In: Proceedings of the American Society for Surface Mining and Reclamation, Tupelo, 8-15 June 2012, pp 103-132

Farr C, Skousen J, Edwards P, Connolly S, Sencindiver J (2009) Acid soil indicators in forest soils of the Cherry River Watershed, West Virginia. Environ Monit Assess 158:343-353

Fike J, Parrish D, Wolf D, Balasko J, Green J, Rasnake M, Reynolds J (2006) Switchgrass production for the upper southeastern USA: influence of cultivar and cutting frequency on biomass yields. Biomass Bioenergy 30:207-213

Gorman J, Skousen J, Sencindiver J, Ziemkiewicz P (2001) Forest productivity and minesoil development under a white pine plantation versus natural vegetation after 30 years. In: Proceedings 18th Annual Meeting, American Society for Surface Mining and Reclamation, Albuquerque, pp 103-111, 2-7 June 2001

Groninger J, Skousen J, Angel P, Barton C, Burger J, Zipper C (2007) Mine reclamation practices to enhance forest development through natural succession. US Office of Surface Mining, Appalachian Regional Reforestation Initiative, Forest
Reclamation Advisory Number 5. http://arri.osmre.gov/FRA/ Advisories/FRA_No.5.pdf

Hicks RJ (1998) Ecology and management of central hardwood forests. John Wiley \& Sons, New York

Keene T, Skousen J (2010) Mine soil reclamation with switchgrass for biofuel production. In: Barnhisel RI (ed) Proceedings 2010 national meeting of the American Society of Mining and Reclamation, Pittsburgh, 5-11 June, 2010. ASMR, Lexington, pp 489-503

Keys RN, Cech FC, Davidson WH (1971). The performance of Austrian pine seed sources on various sites in West Virginia and Pennsylvania. In: NE forest tree improvement conference, Northeast Forest Exp. Stn. U.S. Forest Service, Upper Darby, pp 103-114

Limstrom GA (1960) Forestation of strip-mined land in the Central States. USDA For. Serv. Ctr. States For. Exp. Stn., Agric. Handb.166. USDA, Columbus

Marra M, Keene T, Skousen J, Griggs T (2013) Switchgrass yield on reclaimed surface mines for bioenergy production. J Env Qual 42:696-703

Mickalitis AB, Kutz DB (1949) Experiments and observations on planting areas 'stripped' for coal in Pennsylvania. Pa For Waters $1: 62-70$

Minkler LS (1941) Forest plantation success and soil-site characteristics on old fields in the Great Appalachian Valley. Soil Sci Soc Am Proc 6:396-398

NRCS (U.S. Natural Resource Conservation Service, 2011) Web soil survey. http://websoilsurvey.nrcs.usda.gov/. Accessed Dec 2012

Paone J, Struthers P, Johnson W (1978) Extent of disturbed lands and major reclamation problems in the United States. In: Schaller F, Sutton P (eds) Reclamation of drastically disturbed lands, 1st edn. American Society of Agronomy, Madison, pp 11-22

Parrish D, Fike J (2005) The biology and agronomy of switchgrass for biofuels. Crit Rev Plant Sci 24:423-459

Plass WT (1982) The impact of surface mining on the commercial forests of the United States. In: Kolar CA, Ashby WC (eds) Postmining productivity with trees. Southern Illinois University, Carbondale, pp 1-7

Plass WT (2000) History of surface mining reclamation and associated legislation. In: Barnhisel R, Darmody R, Daniels W (eds) Reclamation of drastically disturbed lands. Agronomy monograph, 41st edn. American Society of Agronomy, Madison, pp 1-20

Reeder J, McGinnies W (1989) Response of established forages on reclaimed mined land to fertilizer $\mathrm{N}$ and $\mathrm{P}$. J Range Mgmt 42:327-332

RickettsTH Dinerstein E, Olson DM, Loucks CJ, Eichbaum W, DellaSalla D, Kavanagh K, Hedao P, Hurley P, Carney K, Abell R, Walters S (1999) Terrestrial Ecoregions of North America: A conservation assessment. Island Press, Washington DC $508 \mathrm{p}$

Ries R, Nilson D (2000) Reclamation considerations for range, pasture, and hay lands receiving $25-66 \mathrm{~cm}$ annual precipitation. In: Barnhisel R, Darmody R, Daniels W (eds) Reclamation of drastically disturbed lands. Agronomy monograph, 41st edn. American Society of Agronomy, Madison, pp 273-301

Riitters K, Wickham J, O'Neill R, Jones B, Smith E (2000) Globalscale patterns of forest fragmentation. Conservation Ecology 4 . http://www.consecol.org/vol4/iss2/art3/. Accessed on 12 July 2010

Schuman G, Taylor E, Rauzi F, Pinchak B (1985) Revegetation of mined land: influence of topsoil depth and mulching method. J Soil Water Conserv 40:249-252

Skousen JG, Call A, Knight RW (1990) Natural revegetation of an unreclaimed lignite surface mine in east-central Texas. Southwestern Nat 35:157-163

Skousen J, Ziemkiewicz P, Venable C (2006) Tree recruitment and growth on 20-yr-old, unreclaimed surface mined lands in West Virginia. International. J Min Reclam Environ 20:142-154 
Skousen J, Zipper C, Burger J, Barton C, Angel P (2011) Selecting materials for mine soil construction when establishing forests on Appalachian mine sites. U.S. Office of Surface Mining, Appalachian Regional Reforestation Initiative. Forest Reclamation Advisory No. 8. http://arri.osmre.gov/FRA/Advisories/FRA_No. 8\%20Soil\%20Materials.PDF

Skousen J, Keene T, Marra M, Gutta B (2013) Reclamation of mined land with switchgrass, Miscanthus, and Arundo for biofuel production. J Am Soc Mining Recl 2:177-191

Skousen J, Brown C, Griggs T, Byrd S (2014) Establishment and growth of switchgrass and other biomass crops on surface mines. J Am Soc Mining Recl, 3 (in press)

Slagle A, Skousen J, Bhumbla D, Sencindiver J, McDonald LM (2004) Trace element concentrations of three soils in West Virginia. Soil Surv Horizons 45(3):73-85

Sutton P, Hall G (1987) Fertilization for forage production on calcareous mined land in Ohio. J Soil Water Conserv 42:361-364

Sweigard R, Burger J, Zipper C, Skousen J, Barton C, Angel P (2007) Low Compaction Grading to Enhance Reforestation Success on Coal Surface Mines. US Office of Surface Mining, Appalachian Regional Reforestation Initiative, Forest Reclamation Advisory Number 3. http://arri.osmre.gov/FRA/Advisories/FRA_No.3.pdf

Torbert JL, Burger JA (2000) Forest land reclamation. In: Barnhisel R, Darmody R, Daniels W (eds) Reclamation of drastically disturbed lands. Agronomy monograph, 41st edn. American Society of Agronomy, Madison, pp 371-398

Tryon EH (1952) Forest cover for spoil banks. West Virginia Agriculture and Forest Experiment Station Bulletin 357. West Virginia University, Morgantown
Wood P, Larkin J, Mizel J, Zipper C, Angel P (2013) Reforestation to Enhance Appalachian Mined Lands as Habitat for Terrestrial Wildlife. US Office of Surface Mining, Appalachian Regional Reforestation Initiative, Forest Reclamation Advisory Number 10

Zipper CE, Winter S (2009) Stabilizing reclaimed mines to support buildings and development. Virginia Cooperative Extension Publication 460-130. Virginia Tech, Blacksburg. http://pubs.ext. vt.edu/460/460-130/460-130.html

Zipper CE, Yates C (2009) Reclaiming mined lands as industrial sites. Virginia Cooperative Extension Publication 460-132. VA: Virginia Tech, Blacksburg

Zipper CE, Burger JA, McGrath JM, Rodrigue JA, Holtzman GA (2011a) Forest restoration potentials of coal mined lands in the eastern United States. J Environ Qual 40:1567-1577

Zipper CE, Burger JA, Skousen JG, Angel PN, Barton CD, Davis V, Franklin JA (2011b) Restoring forests and associated ecosystem services on Appalachian coal surface mines. Environ Manage 47:751-765

Zipper CE, Evans DM, Burger JA, Fields-Johnson CW, Brunner A, Stanton B (2011c). Woody biomass production on post-SMCRA mined lands over three years and comparisons with other studies. In: Barnhisel R (ed), Proceedings 2011 National Meeting of the American Society of Mining and Reclamation. Bismark

Zipper CE, Burger J, Barton C, Skousen J (2013) Rebuilding soils on mined land for native forests in Appalachia, USA. Soil Sci Soc Am J 77:337-349 